\title{
Nonmarine Paleodictyon from the Carboniferous Albert Formation of southern New Brunswick
}

\author{
Ron K. Pickerill \\ Department of Geology, University of New Brunswick, Fredericton, New Brunswick E3B 5A3, Canada
}

Date Received April 6, 1990

Date Accepted June 18, 1990

\begin{abstract}
The ichnogenus Paleodictyon is documented from the Carboniferous (Mississippian - late Toumaisean) nonmarine Albert Formation of southern New Brunswick. This occurrence represents only the second formal recording of the ichnotaxon in a nonmarine setting, as elsewhere Paleodictyon is almost universally a deep-water flysch trace fossil, rarely a shallow marine neritic form. In the Albert Formation Paleodictyon is restricted to strata deposited in a freshwater shallow lacustrine environment and it occurs in association with the ichnotaxa Cochlichnus anguineus, Gordia marina, Helminthopsis tenuis, Palaeophycus striatus, Palaeophycus tubularis and Planolites. Vermiform organisms, possibly annelids, are suggested to have been potential producers of these nonmarine Paleodictyon that probably formed as a result of the regular intersection of the same or different simple burrow systems.
\end{abstract}

On signale l'ichnogenre Paleodictyon dans la Formation continentale carbonifere (Mississippien à Tournaisien tardif) d'Albert au Nouveau-Brunswick méridional. Ceci n'est que la seconde mention formelle de cet ichnotaxon en milieu continental car, ailleurs, Paleodictyon se rencontre en quasi totalité dans des flyschs d'eau profonde et rarement en domaine néritique littoral. Dans la Formation d'Albert, Paleodictyon se confine aux strates accumulées en milieu lacustre d'eau douce peu profonde, en association avec les ichnotaxons Cochlichnus anguineus, Gordia marina, Helminthopsis tenuis, Palaeophycus striatus, Palaeophycus tubularis et Planolites. On suggère que des organismes vermiformes (annélides?) ont produit ces Paleodictyon d'eau douce, dont l'origine est vraisemblablement l'intersection régulière d'un ou de plusieurs réseaux de galeries simples.

[Traduit par le joumal]

\section{INTRODUCTION}

The ichnogenus Paleodictyon Meneghini in Murchison, 1850 is characterized by a honeycomblike network of four- to eight-sided, commonly hexagonal, horizontal meshes that are typically preserved on sandstone bedding surfaces in positive hyporelief, more rarely in negative epirelief (Häntzschel, 1975; Seilacher, 1977). Arguably, it is one of the most easily recognized and commonly reported flysch trace fossils in ichnological literature, ranging throughout the Phanerozoic on a world-wide basis (Swinbanks, 1982). It represents perhaps the most spectacular burrow system of a group of trace fossils known informally as the graphoglyptids (Fuchs, 1895; Seilacher, 1977), which are complex, geometrically patterned, feeding or farming burrow systems also referred to as Agrichnia (Ekdale $e t$ al., 1984). Paleodictyon is commonly preserved in many ancient flysch deposits (Seilacher, 1977; Ekdale, 1980) and until relatively recently in ichnological literature was considered an excellent deep-sea palaeoenvironmental indicator. However, isolated recordings by authors such as Häntzschel (1964), Pacześna (1985) and McMenamin and Schulte McMenamin (1990 - as Protopaleodictyon Ksiażkiewicz) indicated that the ichnogenus could in fact occur in shallow-water marine palaeoenvironments.
To date, I am aware of only a single formally reported occurrence of Paleodictyon in nonmarine strata, which is that by Archer and Maples (1984), as more recently summarized in Maples and Archer (1989). Therefore, the purpose of this short contribution is to record an additional example of the ichnogenus within nonmarine strata from the Carboniferous Albert Formation of southern New Brunswick, eastern Canada.

\section{LOCATION, GEOLOGICAL AND PALAEOENVIRONMENTAL SETTING}

Specimens described here were collected from two roadside outcrops at Norton, southern New Brunswick (Fig. 1), which expose Carboniferous (Mississippian - late Tournaisian) strata of the Albert Formation. More complete details of the locations may be found in Pickerill et al. (1985). The Albert Formation is the medial of three formations that constitute the Late Devonian to Early Carboniferous Horton Group, which was formed in a northeasterly-trending, southwesterly-narrowing, depositional basin known locally as the Moncton Subbasin (Roliff, 1962). This subbasin is one of a series of geographically-widespread subbasins and associated arches or uplifts that constitute the Maritimes Basin of Roliff (1955) and Williams (1974), a post- 


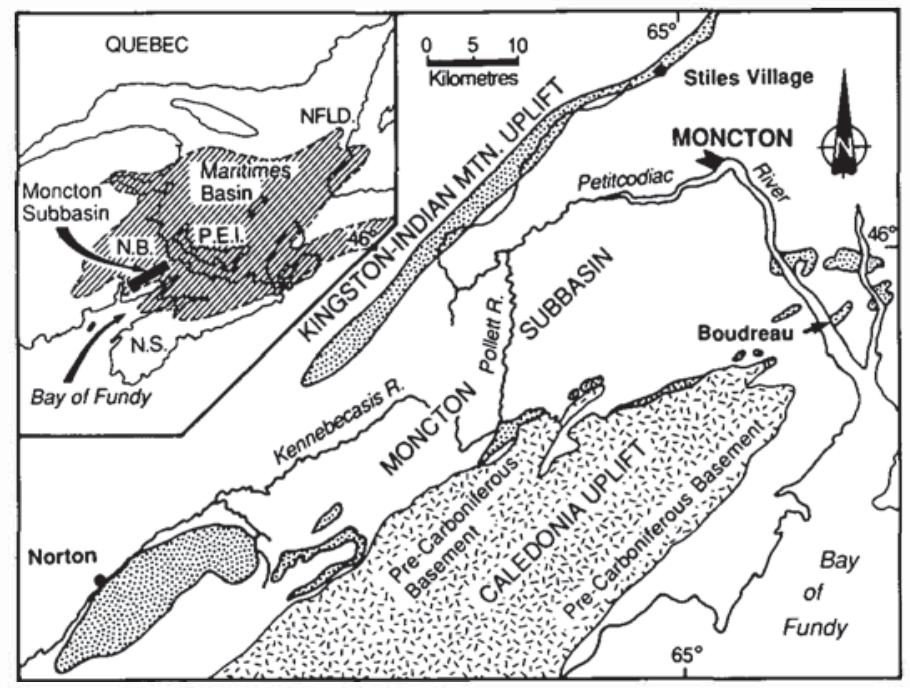

Fig. 1. Simplified sketch illustrating the geographic distribution of the Maritimes Basin of eastern Canada and the Moncton Subbasin of southem New Brunswick. Surface outcrop of the Albert Formation is stippled and Norton is located on the Kennebecasis River in the southeast of the Moncton Subbasin.

Acadian intermontane, successor-type, strike-slip basin in which essentially continental strata accumulated (Bradley, 1982).

As more fully discussed in Pickerill and Carter (1980), Macauley and Ball (1982), Macauley et al. (1984), Pickerill et al. (1985), Smith and Gibling (1987) and Mossman et al. (1987), the Albert Formation accumulated in a continental setting. The sequence essentially comprises grey siliciclastic strata, ranging in thickness from $165 \mathrm{~m}$ to $1800-2000 \mathrm{~m}$ (Smith and Gibling, 1987; Mossman et al., 1987), which contain freshwater palaeoniscid fish (Lambe, 1909) and ostracodes (Greiner, 1974) and poorly preserved but diverse megafloral (Bell, 1929) and freshwater palynomorph and algal assemblages (Utting, 1987). These strata were deposited in a variety of nonmarine environments including alluvial fans, deltas and lakes (Pickerill and Carter, 1980; Pickerill et al., 1985, Foley, 1989).

At Norton, the Albert Formation consists of at least seven, possibly eight, upward-fining and upward-thinning fluvio-deltaic cycles, that occur in association with shallow-water lacustrine strata (Pickerill et al., 1985) (Fig. 2). Fluvio-deltaic cycles are characterized by erosively based, thickly-bedded, coarse conglomerates that pass upwards into interbedded sandstones and mudstones and finally into thinly interbedded siltstones or fine-grained sandstones and mudstones. These strata have been interpreted by Pickerill and Carter (1980) and Pickerill et al. (1985) as representing fluvial channel sequences. The uppermost, commonly desiccated, siltstones and mudstones represent the final depositional phases as a result of channel abandonment or migration. Interestingly, the fluvial channel sequences contain dominantly arthropod-produced trace fossil assemblages, that include Cruziana problematica (Schindewolf),Diplichnites triassicus (Linck), Monomorphichnus lineatus Crimes et al., Rusophycus didymus (Salter), cf. Steinichnus Bromley and Asgaard and Skolithos Haldeman. Lacustrine strata at Norton
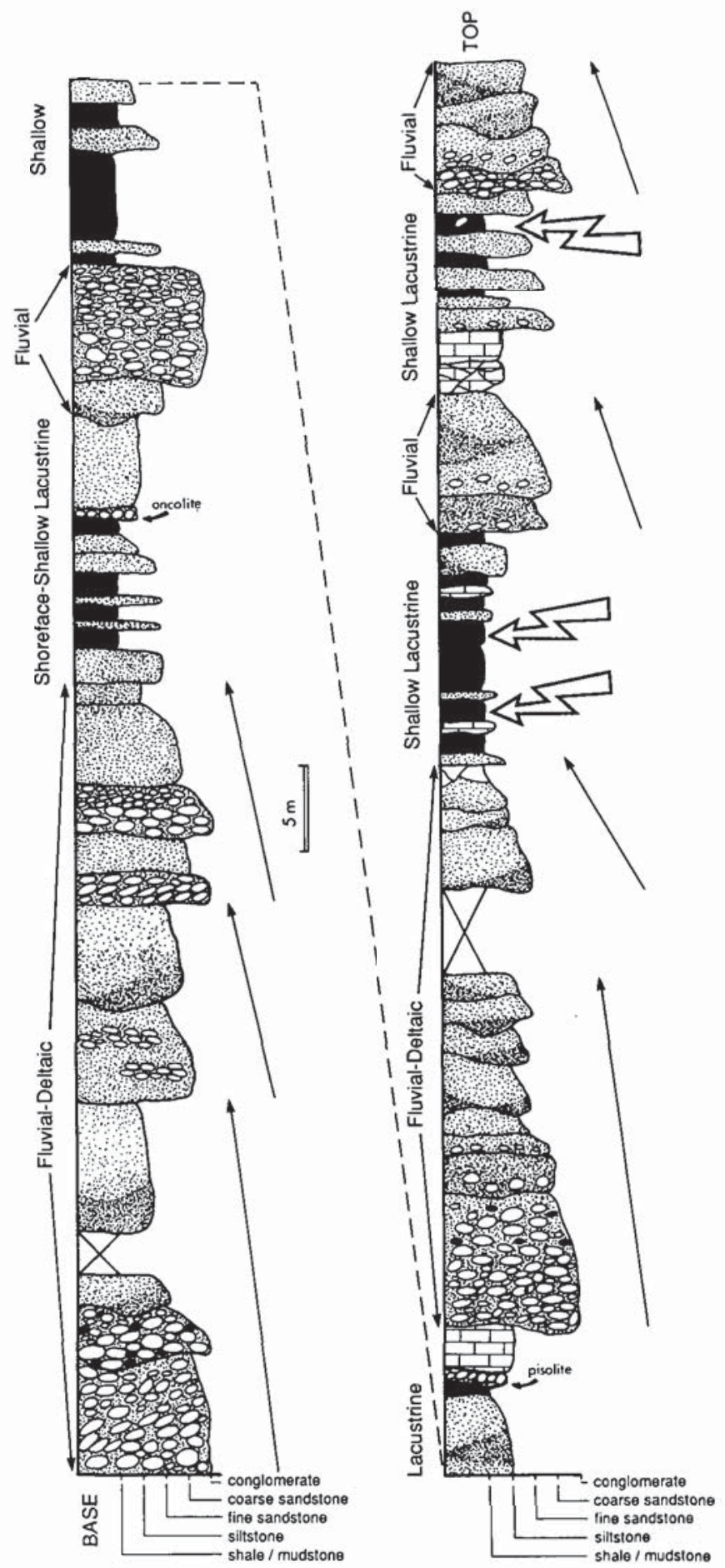

Fig. 2. Simplified, composite, vertical stratigraphic section of the Albert Formation at the two roadside outcrops at Norton. Upward-fining fluvial or fluvio-deltaic cycles are indicated by vertical arrows. Open arrows indicate approximate levels within the sequence where Paleodictyon specimens were collected. Section and environmental interpretation modified after Carter and Pickerill (1985).

comprise interbedded wave-worked sandstones and mudstones, oncolitic horizons, and dominantly thinly interbedded, laminated siltstones and bituminous and sub-bituminous dolomitic 
marlstones and mudstones (Pickerill et al., 1985). The former strata have been interpreted by Pickerill and Carter (1980) and Pickerill et al. (1985) as shoreface lacustrine and the latter as sediments deposited in a slightly deeper and more quiescent lacustrine environment. It is from these latter strata that the specimens of Paleodictyon were collected, occurring in association with Cochlichnus anguineus Hitchcock, Gordia marina Emmons, Helminthopsis tenuis Ksią̇kiewicz, Palaeophycus striatus Hall and Planolites Nicholson.

\section{SYSTEMATIC PALICHNOLOGY}

Ichnogenus Paleodictyon Meneghini in Murchison, 1850

\section{Type ichnospecies Paleodictyon strozzi Meneghini, 1850}

\section{Diagnosis}

Honeycomblike network of four- to eight-sided, commonly hexagonal, horizontal meshes, preserved typically in convex hyporelief, more rarely in concave epirelief. Meshes with or without vertical outlets, of variable size and shape. Outline of entire systems rounded, or more typically hexagonal (after Häntzschel, 1975; Seilacher, 1977; Ksiạżkiewicz, 1977).

\section{Paleodictyon isp.}

(Fig. 3)

\section{Material}

Seven, possibly eight, networks preserved on six slabs. The slabs were collected from talus material immediately adjacent to locations indicated in Figure 2. Figured specimen reposited in the Division of Natural Sciences, New Brunswick Museum, Saint John, New Brunswick (NBMG 6460). Additional specimens housed in the Department of Geology, University of New Brunswick.

\section{Description}

Specimens are preserved in positive relief on the soles of slabs of $1 \mathrm{~cm}$-thick, bioturbated or parallel-laminated, fine- to medium-grained sandstones. Preservation and clarity are variable and typically relatively poor. Gordia marina Emmons, Helminthopsis tenuis Książkiewicz, Palaeophycus striatus Hall, and Palaeophycus tubularis Hall occur on the same soles and, where determinable, they clearly postdate Paleodictyon. Specimens consist of irregularly polygonal, where well-preserved typically hexagonal, horizontal meshes (sensu Seilacher, 1977; Książkiewicz, 1977) that are complete or incomplete. Individual polygons are, diagonally, approximately $5 \mathrm{~mm}$ and of similar size and shape. Riblets are hemicylindrical and thickness varies from 1.5 to $2 \mathrm{~mm}$ depending on height which is typically relatively low, making photographic reproducibility difficult. Riblets are characteristically straight, rarely slightly curved, smooth and thinly lined; course change in riblets is relatively sharp. No vertical outlets observed. Individual nets may cover a surface area of $100 \mathrm{~cm}^{2}$.

\section{Remarks}

Classification of Paleodictyon at the ichnospecific level is still plagued by different authors adopting different criteria (McCann and Pickerill, 1988; Crimes and Crossley, in press). For example, Książkiewicz $(1970,1977)$ considered mesh size, regularity and thickness of bordering riblets as important ichnospecific criteria. Seilacher (1977), however, considered mesh plan shape to be more important and subdivided Paleodictyon into three subichnogenera (Squamodictyon, Glenodictyum and Ramidictyon) based essentially on this criterion. Both schemes have their inherent difficulties and a taxonomic revision of the ichnogenus is still clearly warranted. Because of this, together with the generally poor preservation of the material, the specimens are only identified to the ichnogeneric level (cf. Crimes and Crossley, in press).

\section{DISCUSSION}

Distinguishing between biogenic and non-biogenic sedimentary structures in the geological record is on occasion extremely hazardous and has been the topic of much discussion in the literature (e.g., Cloud, 1973; Karcz et al., 1974; Häntzschel, 1975; Boyd, 1975; Ekdale et al., 1984). Thus, in view of the importance of the structures described herein, initially it must be demonstrated that they are biogenic as distinct from non-biogenic in origin. This is considered relevant because several authors have described Paleodictyon-like structures in the geological record but have interpreted them as having been produced by various inorganic mechanisms. For example, Fliche (1906) erected Rivularites for morphologically similar structures believing them to be algal in origin. However, Kummel and Teichert (1970) interpreted these structures as systems of capped interference ripples or as wrinkle marks (Runzelmarken), prompting Häntzschel (1975) to regard them as pseudofossils. Osgood (1970) described ?Paleodictyon from the Ordovician of Ohio but believed it to be a tool mark possibly produced by a receptaculitid rather than a biogenic structure. Benton and Gray (1981) described similar structures to those described here but from the Lower Silurian of the Welsh Borders and interpreted them as bounce marks produced by favositid corals. Finally, Boyd (1975) noted that shrinkage cracks producing small regular polygons could, if preserved in the geological record, potentially resemble Paleodictyon. Indeed, a number of authors have produced hexagonal (e.g., Kuenen, 1965, p. 24, fig. 3) or polygonal (e.g., Burst, 1965, p. 351, fig. 5) structures under laboratory conditions, and formed as a result of synaeresis, which superficially resemble Paleodictyon.

Perhaps the most comprehensive criteria proposed to date in differentiating biogenic from non-biogenic structures are those by Ekdale et al. (1984). Of the various criteria these authors discuss, and obviously not all can be applied, the following observations suggest a biogenic origin for the specimens 


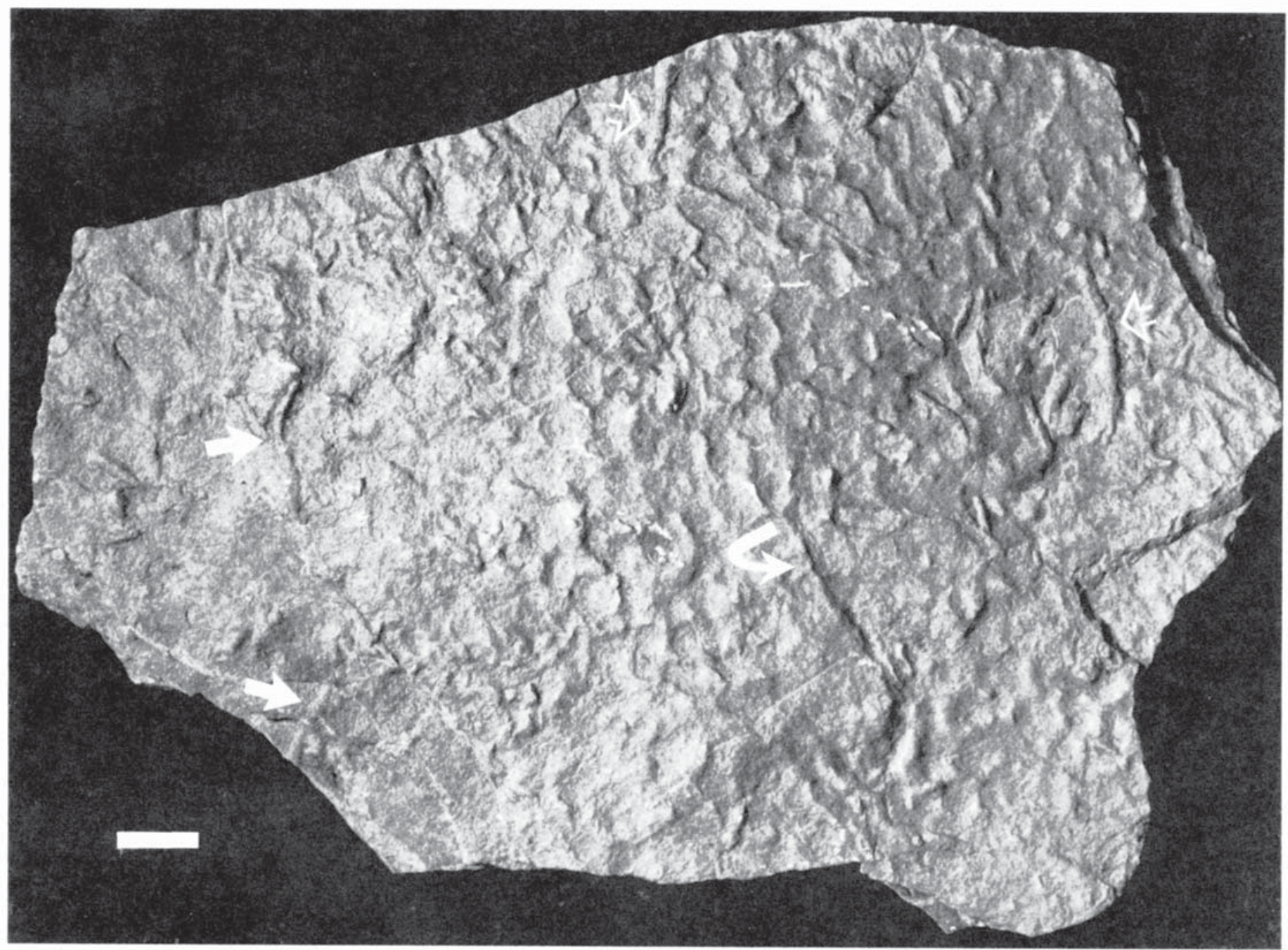

Fig. 3. Paleodictyon isp. network on the sole of a $1 \mathrm{~cm}$-thick, parallel-laminated, medium-grained sandstone from lacustrine strata of the Albert Formation at Norton (NBMG 6460). Open arrows indicate examples of Palaeophycusstriatus and solid arrows Palaeophycus tubularis. Solid curved arrow illustrates a Palaeophycus-like burrow in continuation with the Paleodictyon meshes. Bar scale is $1 \mathrm{~cm}$.

described here:- an obvious lack of current alignment or orientation and associated current-produced structures, the generally uniform dimensions of the nets and their regular, if somewhat complex, geometric pattern of relatively uniform continuity, the presence of a thin lining and last, but not least, the presence of other trace fossils on the same sandstone soles. There is no evidence to suggest even episodic exposure of the strata containing the specimens and therefore, unlike two of the examples noted above, they cannot be regarded as Runzelmarken or desiccation features, both of which require at least periodic exposure of the substrate prior to formation (Allen, 1985). The possibility, that they resulted from synaeresis requires additional discussion, particularly as several structures previously regarded as biogenic in origin have subsequently been attributed to this process. Manchuriophycus Endo and Rhynsonetron Hofmann are two such examples(see Glaessner, 1969; Hofmann, 1971; Häntzschel, 1975). Plummer and Gostin (1981) have provided a review of shrinkage cracks and have discussed in detail the origin and morphology of synaeresis structures. They state (Plummer and Gostin, 1981, p. 1153) that synaeresis cracks are generally discontinuous, spindle, or sinuous, in shape and possess $\mathrm{V}$ - or $\mathrm{U}$ shaped cross-sections. While polygonal structures resulting from synaeresis were possible, Plummer and Gostin (1981) emphasized that they were extremely rare. The experimentallyproduced networks of Kuenen (1965) and Burst (1965) are considerably more irregular and larger in scale than the structures described herein. Furthermore, the Albert Formation specimens are not $\mathrm{V}$ - or U-shaped in cross-section and individual networks cover only a restricted surface area of any given bedding plane. Salinity changes, the dominant causative factor in the production of synaeresis structures (Plummer and Gostin, 1981), are likely to have been negligible in a freshwater lacustrine setting. Finally, some examples exhibit Palaeophycus-like burrows that connect directly to individual polygons (cf. Kushlin, 1982; Paczeŝna, 1985; Crimes and Crossley, in press). These observations suggest that the structures were not produced by synaeresis, and to echo the words of the emminent theoretical and observational sedimentologist, Professor J.R.L. Allen, “....whether synaeresis occurs naturally has never been proved...." (Allen, 1984, p. 553). 
Corals and receptaculitids are, of course, exclusively marine organisms and are obviously not candidates with respect to the production of these structures. Collectively, therefore, these observations suggest a biogenic origin.

Morphologically-similar biogenic structures, but only described from the Recent, include the bee-nest patterns described by Sando (1972) and the tadpole nests of many authors as reviewed in Cameron and Estes (1971). Interestingly, Boyd (1975) noted the superficial resemblance of Sando's (1972) beenest patterns to Paleodictyon. Bees and frogs obviously cannot be considered as serious candidates for the production of the specimens here because the bee-nest patterns described by Sando (1972) are produced in lithified substrates and frogs did not appear until the Jurassic (Cameron and Estes, 1971). Additionally, of course, tadpole nests occur as positive features on upper substrate surfaces. Indeed, the producers of the structures described here remain enigmatic, but this is not unusual in ichnological studies, and as noted by Häntzschel (1975) Paleodictyon is one of the most famous Problematica and its origin has been discussed for more than a century.

Książkiewicz (1977), Crimes (1977), Seilacher (1977), Kushlin (1982) and Swinbanks (1982), amongst others, have provided detailed reviews on the construction and possible producers of Paleodictyon and it seems likely that a variety of organisms from different phyla can be equally responsible. However, two observations suggest that possible producers of the material here were vermiform organisms (cf. Crimes, 1977), possibly annelids. First, Paleodictyon occurs on the same surfaces as other trace fossils commonly attributed to the activity of vermiform organisms, particularly annelids, such as Gordia marina, Helminthopsis tenuis and Palaeophycus (see Hăntzschel, 1975; Książkiewicz, 1977; Pemberton and Frey, 1982). Second, the external portions of some networks rarely exhibit simple, horizontal Palaeophycus-like burrows directly connected with the specimens of Paleodictyon (e.g., arrowed in Fig. 3). Similar examples have previously been figured by Kushlin (1982,p. 271, fig. 3) and Pacześna (1985, p. 595, pl. 2, fig. 1). More recently, Crimes and Crossley (in press) have described several examples of both Gordia Emmons and Helminthopsis Heer which pass laterally into both Paleodictyon and the related graphoglyptid Squamodictyon Vyalov and Golev.

Nowak (1959), Chamberlain (1971), and Crimes (1977), amongst others, have discussed the manner of construction of Paleodictyon and other graphoglyptid networks and this latter observation would tend to confirm their conclusions that many examples, but not necessarily all, result from the regular intersection of the same or different simple burrow systems. As also noted by Seilacher (1977, p. 322), Paleodictyon networks can also be derived from meandering, spiralling or branching behaviour. The concern expressed by Pollard (1988) that 'Paleodictyon-like' structures in British Westphalian nonmarine strata, and produced by intersection of meandering, sine-like, burrows or trails of Cochlichnus is regarded as unwarranted. Indeed, several of the examples described here could equally be regarded as the fortuitous intersection at extremely regular intervals of the sharply zigzag-shaped, uniramous graphoglyptid burrow of Belorhaphe Fuchs.
Although preservation of the nets or meshes in the material described here is not ideal and often incomplete this is not cause for concern in allocating it to Paleodictyon. Incomplete preservation of meshes within single networks is, in fact, commonplace in Paleodictyon (e.g., Webby, 1969; Chamberlain, 1971; Crimes et al., 1981; Miller, 1986) and examples exist in the literature which are far less convincing than those described here (e.g., Crimes and Anderson, 1985, p. 328, fig. 10.4). To my knowledge, this is only the second formal recording of the ichnogenus in undoubted nonmarine strata. The previously noted examples described and figured by Archer and Maples (1984, p. 453, fig. 4G) do appear to represent Paleodictyon, although several difficulties still remain to be resolved with them. First, they are stated in the text to be preserved as epirelief ridges or concave hyporeliefs, a preservation style atypical of Paleodictyon. Yet their figured example is stated to be preserved in convex hyporelief. Second, Archer and Maples' (1984) material occurs within strata interpreted as floodplain and lacustrine but which occur in direct association with marine strata. The possibility of a marine influence cannot therefore be totally excluded and, as previously noted, even given that their identification is correct, there exists several recordings of shallow-water marine Paleodictyon.

This occurrence of Paleodictyon reiterates the observation that the ichnotaxon can occur in nonmarine environments. As summarized in Maples and Archer (1989), however, many ichnotaxa previously regarded as exclusively marine, particularly in the last decade, have now been recorded in continental strata and are continuing to be documented (e.g., Ekdale et al., 1989). Although caution must be exercised on its use as a palaeoenvironmental indicator, Paleodictyon still remains, however, one of the most useful deep-water marine trace fossil ichnotaxa. The occurrence of nonmarine Carboniferous Paleodictyon as formally described herein and by Archer and Maples (1984) (and possibly the material noted by Pollard (1988) that was originally described in a thesis which, to date, has proved unobtainable) does, however, raise several important questions (G. Narbonne, personal communication, 1990). Is the function of the burrows the same as in marine examples; do these nonmarine examples reflect migration from the marine realm or convergent behavioural evolution in marine and fresh waters? The answer to these questions and other equally important enigmas regarding Paleodictyon must await more detailed research, particularly with respect toother possible, but, at present, undocumented nonmarine occurrences.

\section{ACKNOWLEDGEMENTS}

I wish to thank A. Gomez, R. McCulloch and D. Tabor for their help in all phases of the preparation of this manuscript. Ialso thank D. Carter and J. Wiley for assistance in the collection of trace fossil material from the Albert Formation, which has been underway for at least twelve years. Hans Hofmann discovered the first specimen of Paleodictyon at Norton in 1985 on a G.A.C.J M.A.C. field trip and, though somewhat amusingly, provided an identification. R. MacNaughton, G. Narbonne and D. Fillion provided constructive and very helpful reviews of the initial manuscript; all agree with the identification of the material 
having viewed the specimens. Use of isp. instead of ichnosp. as the standard abbreviation for ichnospecies follows the suggestion of R.G. Bromley. Financial support was provided by a Natural Sciences and Engineering Council of Canada operating grant 0GP0003857, which is gratefully acknowledged.

ALLEN, J.R.L. 1984. Sedimentary structures, their character and physical basis. Developments in Sedimentology, 30. Elsevier, Amsterdam, Oxford, New York, Tokyo, 663 p.

_. 1985. Wrinkle marks: an intertidal sedimentary structure due to aseismic soft-sediment loading. Sedimentary Geology, 41, pp. $75-95$.

ARCHER, A.W. and MAPLES, C.G. 1984. Trace-fossil distribution across a marine-to-nonmarine gradient in the Pennsylvanian of southwestern Indiana. Joumal of Paleontology, 58, pp. 448-466.

BELL, W.A. 1929. Horton-Windsor District, Nova Scotia. Geological Survey of Canada, Memoir 155, $268 \mathrm{p}$.

BENTON, M.J. and GRAY, D.I. 1981. Lower Silurian distal shelf storm-induced turbidites in the Welsh Borders: sediments, tool marks and trace fossils. Journal of the Geological Society of London, 138, pp. 675-694.

BOYD, D.W. 1975. False or misleading traces. In The Study of Trace Fossils. Edited by R.W. Frey. Springer Verlag, Berlin, Heidelberg, New York, pp. 65-83.

BRADLEY, D.C. 1982. Subsidence in Late Paleozoic basins in the Northern Appalachians. Tectonics, 1, pp. 107-123.

BURST, J.F. 1965. Subaqueously formed shrinkage cracks in clay. Journal of Sedimentary Petrology, 35, pp. 348-353.

CAMERON, B. and ESTES, R. 1971. Fossil and Recent "tadpole nests": a discussion. Joumal of Sedimentary Petrology, 41, pp. 171-178.

CARTER, D.C. and PICKERILL, R.K. 1985. Algal swamp, marginal and shallow evaporitic lacustrine lithofacies from the late $\mathrm{De}$ vonian-early Carboniferous Albert Formation, southeastem New Brunswick, Canada. Maritime Sediments and Atlantic Geology, 21, pp. 69-86.

CHAMBERLAIN, C.K. 1971. Morphology and ethology of trace fossils from the Ouachita Mountains, southeast Oklahoma. Journal of Paleontology, 45, pp. 212-246.

CLOUD, P. 1973. Pseudofossils: A Plea for Caution. Geology, 1, pp. 123-127.

CRIMES, T.P. 1977. Modular construction of deep-water trace fossils from the Cretaceous of Spain. Journal of Paleontology, 51, pp. 591605.

CRIMES, T.P. and ANDERSON, M.M. 1985. Trace fossils from late Precambrian-Early Cambrian strata of southeastern Newfoundland (Canada): temporal and environmental implications. Journal of Paleontology, 59, pp. 310-343.

CRIMES, T.P. and CROSSLEY, J.D. In press. A diverse ichnofauna from the Silurian flysch of Aberystwyth, Wales. Geological Journal.

CRIMES, T.P., GOLDRING, R., STUIJVENBERG, J. VAN, and WINKLER, W. 1981. Trace fossil assemblages of deep-sea fan deposits, Gurnigel and Schlieren flysch (Cretaceous-Eocene), Switzerland. Eclogae Geologicae Helvetiae, 74, pp. 953-995.

EKDALE, A.A. 1980. Graphoglyptid Burrows in Modern Deep-Sea Sediment. Science, 207, pp. 304-306.

EKDALE, A.A., BROMLEY, R.G., and PEMBERTON, S.G. 1984. Ichnology: The Use of Trace Fossils in Sedimentology and Stratigraphy. Society of Economic Paleontologists and Mineralogists, Short Course Number 15, 317 p.
EKDALE, A.A., BROWN, F.H., and FEIBEL, C.S. 1989. Nonmarine Macroborings in Early Pleistocene Algal Biolithites (Stromatolites) of the Turkana Basin, Northern Kenya. Palaios, 4, pp. 389396.

FLICHE, P. 1906. Flore fossile du Trias en Lorraine et en FrancheCompté. Société des Sciences de Nancy, Bulletin 6, pp. 1-66.

FOLEY,S.L. 1989. Geology of the Stoney Creek Oil and Gas Field, and its implications regarding the tectonic evolution of the eastern Moncton Subbasin, New Brunswick. New Brunswick Department of Natural Resources and Energy, Minerals and Energy Division, Geoscience Report 89-1, 77 p.

FUCHS, T. 1895. Studien uber Fucoiden und Hieroglyphen. Akademie der Wissenschaften zu Wien, mathematisch-naturwissenschaftliche Klasse, Abhandlungen, 62, pp. 369-448.

GLAESSNER, M.F. 1969. Trace fossils from the Precambrian and basal Cambrian. Lethaia, 2, pp. 369-393.

GREINER, H. 1974. The Albert Formation of New Brunswick: a Paleozoic lacustrine model. Geologische Rundschau, 63, pp. $1102-1113$.

HÄNTZSCHEL, W. 1964. Spurenfossilien und Problematica im Campan von Beckum (Westf.). Fortschrifte in der Geologie von Rheinland und Westfalen, 7, pp. 295-308.

1975. Trace fossils and Problematica. In Treatise on Invertebrate Paleontology, Part W, Miscellanea, Supplement 1. Edited by C. Teichert. Geological Society of America and the University of Kansas Press, Boulder, Colorado, Lawrence, Kansas, 269 p.

HOFMANN, H.J. 1971. Precambrian fossils, pseudofossils, and problematica in Canada. Geological Survey of Canada, Bulletin $189,146 \mathrm{p}$.

KARCZ, I., ENOS, P., and LANGILLE, G. 1974. Structures generated in fluid stressing of freshly deposited clays resemble ichnofossils. Geology, 2, pp. 289-290.

KSIAŻKIEWICZ, M. 1970. Observations on the ichnofauna of the Polish Carpathians. In Trace fossils. Edited by T.P.Crimes and J.C. Harper. Geological Journal, Special Issue 3, Seel House Press, Liverpool, pp. 283-322.

- 1977. Trace fossils in the flysch of the Polish Carpathians. Palaeontologica Polonica, 36, pp. 1-208.

KUENEN, PH.H. 1965. Value of experiments in geology. Geologie en Mijnbouw, 44, pp. 22-36.

KUMMEL, B. and TEICHERT, C. 1970. Stratigraphy and paleontology of the Permian-Triassic boundary beds, Salt Range and TransIndus Ranges, West Pakistan. In Stratigraphic boundary problems, Permian and Triassic of West Pakistan. Edited by B. Kummel and C. Teichert. Geology Department of the University of Kansas, Special Publication 4, $110 \mathrm{p}$.

KUSHLIN, B.K. 1982. On the algal nature of Paleodictyon. International Geology Reviews, 24, pp. 269-278.

LAMBE, L.M. 1909. The fish fauna of the Albert Shales of New Brunswick. American Journal of Science, 28, pp. 165-174.

MACAULEY, G. and BALL, F.D. 1982. Oil shales of the Albert Formation. New Brunswick Department of Natural Resources, Mineral Resources Branch, Open File 82-12, 173 p.

MACAULEY, G., BALL, F.D., and POWELL, T.G. 1984. A review of the Carboniferous Albert Formation oil shales, New Brunswick. Bulletin of Canadian Petroleum Geology, 32, pp. 27-37.

MAPLES, C.G. and ARCHER, A.W. 1989. The potential of Paleozoic nonmarine trace fossils for paleoecological interpretations. Palaeogeography, Palaeoclimatology, Palaeoecology, 73, pp. 185 . 195.

McCANN, T. and PICKERILL, R.K. 1988. Flysch trace fossils from 
the Cretaceous Kodiak Formation of Alaska. Journal of Paleontology, 62, pp. 330-348.

McMENAMIN, M.A.S. and SCHULTE McMENAMIN, D.L. 1990. The Emergence of Animals; the Cambrian breakthrough. Columbia University Press, New York, 217 p.

MILLER, W. 1986. Discovery of trace fossils in Franciscan turbidites. Geology, 14, pp. 343-345.

MOSSMAN, D., MACEY, J.F., and LEMMON, P.D. 1987. Diagenesis in the lacustrine facies of the Albert Formation, New Brunswick, Canada: a geochemical evaluation. Bulletin of Canadian Petroleum Geology. 35, pp. 239-250.

MURCHISON, R.I. 1850. Memoria sulla struttura geologica delle Alpi, delle Apennini e dei Carpazi. Stamperia granucale, Firenze, 528 p.

NOWAK, W. 1959. Palaeodictyum w. Karpatach fliszowych. Kwartalnik Geologiczny, 3, pp. 103-125.

OSGOOD, R.G. 1970. Trace fossils of the Cincinnati area. Paleontographica Americana, 6, pp. $277-444$.

PACZESNA, J. 1985. Ichnorodzaj Paleodictyon Meneghini z dolnego kambru Zbilutki (Góry Swietkrzyskie). Kwartalnik Geologiczny, 29, pp. 589-596.

PEMBERTON, S.G. and FREY, R.W. 1982. Trace fossil nomenclature and the Planolites - Palaeophycus dilemma. Journal of Paleontology, 56, pp. 843-881.

PICKERILL, R.K. and CARTER, D.C. 1980. Sedimentary facies and depositional history of the Albert Formation. New Brunswick Department of Natural Resources, Open File Report 80-3, 132 p.

PICKERILL, R.K., CARTER, D., and ST. PETER, C. 1985. Albert Formation - oil shales, lakes, fans and deltas. Geological Association of Canada, Mineralogical Association of Canada, Excursion 6, Fredericton, New Brunswick, 75 p.

PLUMMER, P.S. and GOSTIN, V.A. 1981. Shrinkage cracks: desic- cation or synaerisis? Journal of Sedimentary Petrology, 51, pp. $1147-1156$

POLLARD, J.E. 1988. Trace fossils in coal-bearing sequences. Journal of the Geological Society, London, 145, pp. 339-350.

ROLIFF, W.A. 1955. Exploration for oil and gas in eastern Canada. Proceedings of the Geological Association of Canada, 7, pp. 61-81. . 1962. The Maritime Carboniferous basin of eastem Canada. Proceedings of the Geological Association of Canada, 14, pp. 2141.

SANDO, WJ. 1972. Bee-nest pseudofossils from Montana, Wyoming and southwest Africa. Journal of Paleontology, 46, pp. 421-425.

SEILACHER, A. 1977. Pattern analysis of Paleodictyon and related trace fossils. In Trace fossils 2. Edited by T.P. Crimes and J.C. Harper. Geological Journal, Special Issue 9, Seel House Press, Liverpool, pp. 289-334.

SMITH, W.D. and GIBLING, M. 1987. Oil shale composition related to depositional setting: a case study from the Albert Formation, New Brunswick, Canada. Bulletin of Canadian Petroleum Geology, 35, pp. 409-487.

SWINBANKS, D.D. 1982. Paleodictyon: The Traces of Infaunal Xenophyophores? Science, 218, pp. 47-49.

UTTING, J. 1987. Palynostratigraphic investigation of the Albert Formation (Lower Carboniferous) of New Brunswick, Canada. Palynology, 11, pp. 73-96.

WEBBY, B.D. 1969. Trace fossils (Pascichnia) from the Silurian of New South Wales, Australia. Paläontologische Zeitschrift, 43,pp. 81-94.

WILLIAMS, E.P. 1974. Geology and petroleum possibilities in and around the Gulf of St. Lawrence. Bulletin of American Association of Petroleum Geologists, 58, pp. 1137-1155. 